\title{
Sleep and Psychiatry in Children
}

Editors

JOHN H. HERMAN

MAX HIRSHKOWITZ

\section{SLEEP MEDICINE CLINICS}

www.sleep.theclinics.com

Consulting Editor

TEOFILO LEE-CHIONG Jr

June 2015 • Volume 10 - Number 2 